\title{
Prairie Dogs
}

\section{By Ralph R. Stueck, Abernethy}

Hiave you ever visited the home

the Prairie Dog? The only $x \circ$ ralaining dog town in the Commonwealth is in the valley of the Frenchman Creek, about 12 miles southeast of the little town of $\mathrm{Val}$ Marie, Sask. At this present moment, I am at that very spot with my iback against my "Wandering Wigwam" overlooking the weird, lonely range of dog-town. Pencil in hand, I am writing on the back of a Royal Bank calendar to stir your interest in our prairie phenomena.

Of all the animals I have ever captured for zoos, the Prairie Dog is the strangest and most talked of. Yet, less than five per cent of Canadians have actually seen a live Prairie Dog. In this vicinity there are several dog towns, but they are in such remote places that the general public sees little of this animal that has lived on the prairies for centuries.

Like the desert rabbit, the Prairie Dog needs no water other than that obtained from the short dry grass that grows in dog-town. He lives in a colony with laws that every citizen abides by. $\mathrm{He}$ is a busy-body, and right now (July 10) I can see with binoculars from a distance of half a mile that he is busy cutting and piling grass to dry for winter fodder. It is "haying time" of course, and possibly harvest also, and with no labour bills to pay either!

The den of the Prairie Dog is six inches in diameter, twenty or more feet deep, and almost perpendicular. The opening rises above ground like a doughnut. This doughnut serves as a verandah, running water off during flood rain storms. It is made of packed, hard clay. When it is raining, the Prairie Dogs mortar and trowel the inner wall with their noses as a dog buries a bone and packs the ground afterwards with his nose.

Living in a colony, the Prairie Dogs are very sociable in their habits. They often meet in groups of eight or ten and seem to chat together while rubbing noses, hop- ping up and down and repeating the call "ee-ee". During mid-winter they hibernate together below the frost line, where there are no fuel bills or meal tickets to pay. That beautiful long sleep takes three to six hours to awaken from.

Such is the home of the Prairie Dog. If it were possible, good reader, I would that you could sit righit here with me and view to your heart's content a true prairie scene.

In this day of great travel, the tourist is always fascinated by roadside attractions. In the future I would like to see a scenic highway up the Qu'Appelle Valley and a little Prairie Dog town established along the way where the tourist could stop and view at leisure one of the wonders of the prairies.

EDITOR'S NOTE: A recent study of the Prairie Dog has just come to the editor's desk. It is Ronald E. Smith's Natural History of the Prairie Dog in Kansas, miscellaneous publication No. 16 of the University of Kansas, Museum of Natural History, published June 17,1958 . The 36-page publication deals with historical background, nature of the study and methods follawed, description and distribution of the Prairie Dog, food habits, behaviour, molt and pelage, reproduction, burrows, and population changes.

Ronald Smith studied Prairie Dogs from June of 1955 to June of 1957, in Barber County, in one of the large (115 acres) Prairie Dog towns in Kansas by means of observation and live trapping, supplemented by labcratory investigations. The town he studied is at least 30 years old. In the last 52 years, almost $2,442,955$ acres of Prairie Dog towns have been destroyed in Kansas; less than 57,145 acres of Prairie Dog towns remain in the state and 20,000 of these acres were scheduled for poisoning by the end of 1957 . Because of their gregariousness, Prairie Dogs are easily poisoned and whole towns thus completely destroyed. In the light of this destruction, Mr. Smith concluded his study with a strong plea-"that the farmer-rancher think of control of these animals instead of their total destruction. He has a two-fold obligation in this connection to his progeny; 1) leave his land in better condition than when he received it; 2 ) retain the aesthetic value inherent in the native plants and animals on that land. Proper management of cattle will insure a good cover of grass that is of monetary value to the farmer, will fulfill his obligation to his progeny, and will control numbers of the prairie dog without annihilating the species (since overgrazing of the range by cattle or bison has been shown to be necessary before the Prairie Dog can successfully establish itself)."

Individuals may obtain this bulletin by writing to the Museum of Natural History, Univ. of Kansas, Lawrence, Kansas (send money to cover cost of mailing). 